\title{
ENDOGENOUS CHEMICAL CONSTITUENTS IN HARDWOOD STEM CUTTINGS OF GUAVA (Psidium guajava L.) IN RELATION TO ROOTING ABILITY.
}

Samaan, L. G. ${ }^{1}$; E. F. A. El-Dengawy² and Maiada E. El-Zayat ${ }^{1}$

${ }_{1}^{1}$ Pomology Dept., Fac. Agric., Mans. Univ., Egypt.

2 Pomology Dept., Fac. Agric., Damietta branch, Mans. Univ., Egypt.

\begin{abstract}
The present experiment included three growth and root promoting regulators, Indole butyric acid (IBA) solution at $4000 \mathrm{ppm}$, Hydrogen Peroxide $\left(\mathrm{H}_{2} \mathrm{O}_{2}\right)$ solution at $3.5 \%$ and Vitamin $B_{12}$ solution at $24 \mathrm{mg} / \mathrm{L}$. They were used either solely or in combination along with their interactions with split wounding process at the basal portion of hardwood stem cuttings $(5 \mathrm{~cm})$ detached from fruiting guava trees (Psidium guajava L.). Just before inserted the non-wounded and wounded cuttings in planting medium (Sand and Peatmoss 1:1 v/v), they were dipped in each of the tested solutions for 30 second. The control was untreated cuttings just pre-planting dipped in distilled water for 30 second. The effect of treatments under study on certain chemicals content in basal portion of the treated cuttings was tested. Such chemicals included level of nitrogen and carbohydrate contents, $\mathrm{C} / \mathrm{N}$ ratio and phenol contents. The relationship among these chemical constituents in cuttings basal and their rooting ability was the main target of the current research. Rooting ability was estimated through the measurement of 4 root parameters, rooting percentage, number of adventitious primary roots, adventitious primary root length and number of secondary (lateral) roots per cutting.

Results obtained in this experiment indicated that the chemical constituents in both non-wounded and wounded cuttings were significantly affected by various growth and root promoters along with the interactions between them. As for the estimated relationships, it was noticed that cuttings of $\mathrm{T}_{5}$ [Dipping in $\left(\mathrm{H}_{2} \mathrm{O}_{2}+\mathrm{IBA}\right)$ and $\mathrm{T}_{12}$ (Wounded followed by Dipping in $\mathrm{H}_{2} \mathrm{O}_{2}$ and in IBA)], which were determined an appropriate level of $\mathrm{N}$ contents, the high value of carbohydrates and $\mathrm{C} / \mathrm{N}$ ratio as well as low phenols content, were the most favorable cuttings to record higher rooting percentage and to form adventitious roots of good qualities compared with those of the other treatments. On the other hand, both non-wounded and wounded cuttings which had non-appropriate level of $\mathrm{N}$ contents, the lower values of carbohydrates and $\mathrm{C} / \mathrm{N}$ ratio along with higher phenols either completely failed to induce adventitious roots or tabulated significantly lower rooting percentage and the induced roots were of poor characteristics.
\end{abstract}

\section{INTRODUCTION}

Research work carried out on the vegetative propagation of guava trees through stem cuttings has revealed that they are difficult to root and the less root formation is a problem in this case (Tahir et al., 1998). Consequently, the usual method to propagate guava trees is by seed. This method does not insure production of trees true to type and they take along time to start bearing. 
Overcome this problem to enhance root formation was the subject of various investigators. They tried with certain vegetative propagation methods such as budding, grafting and air layering, but very little success is reported. However, they found that the applied stem cuttings with different types may be a suitable alternative to produce quality guava trees under the use of various root promoting hormones (Bleasdale, 1984; Hartmann and Kester, 1985; Luis et al., 1986; Mukhopadhaya and Sen, 1998 and Mukhtar et al., 1998). In other experiments carried out to identify the relationship between rooting ability and endogenous rooting promoters and inhibitors extracted from cuttings, the investigators indicated that during rooting and primordial formation many biochemical and physiological changes were occurred such as an increase in chemical constituents and in activities of several root promoting hormones and enzymes (Um and Yeam, 1987; Shin et al., 1988 and YongKwean and KiSun, 1996).

The present research is a trail in this line. It was designed to spotlight on the relationship between rooting ability and endogenous level of nitrogen and carbohydrate contents, $\mathrm{C} / \mathrm{N}$ ratio and phenols content in basal portion of guava wounded and non-wounded hardwood stem cuttings. The effect of preplanting treatments with 3 solutions of root promoting chemicals on these chemical constituents was also considered.

\section{MATERIALS AND METHODS}

Endogenous levels of nitrogen, carbohydrates, $\mathrm{C} / \mathrm{N}$ ratio and phenols content were determined in basal portion $(5 \mathrm{~cm})$ of hardwood cuttings of guava trees (Psidium guajava L.) after 2 weeks from planting date (March $20)$. The source of cuttings in this study were shoots on guava trees at 15year-old grown in a private orchard located at Om EL-Reda, Damietta governorate, Egypt during 2008 and 2009 seasons. The tested cuttings were made of uniform size $20 \mathrm{~cm}$ long and nearly $1 \mathrm{~cm}$ thick having at least 4 buds and 2 mature leaves. Pre-planting they were divided into 3 groups. Cuttings of one group were split wounded at the basal portion $(5 \mathrm{~cm})$ while they were still on mother trees in the first week of March, two weeks before they were taken; however those of the $2^{\text {nd }}$ group were left non-wounded. Both groups just before inserted in planting medium were subjected to dipping for 30 second in solutions of IBA at $4000 \mathrm{ppm}, \mathrm{H}_{2} \mathrm{O}_{2}$ at $3.5 \%$ and $\mathrm{V}_{\mathrm{B} 12}$ at $24 \mathrm{mg} / \mathrm{L}$ solely or in combinations. The control was cuttings of the $3^{\text {rd }}$ group just preplanting dipped in distilled water for 30 second. The cuttings were planted in polyethylene black bags $30 \mathrm{~cm}$ in diameter at a depth of $5-6 \mathrm{~cm}$. Each contained planting medium of sand and peatmoss $1: 1(\mathrm{v} / \mathrm{v})$ and 12 cuttings per bags were planted in March 20 of the 2 tested seasons. The planted bags were placed on the soil surface of greenhouse at a private nursery equipped with mist irrigation unit. Immediately after planting, the cuttings were irrigated.

Rooting percentage, number and length of adventitious primary roots and number of secondary (lateral) roots per cutting at 3-month-old from planting date were measured. To analyze nitrogen, carbohydrates, $\mathrm{C} / \mathrm{N}$ ratio and phenols content in the basal portion of the treated cuttings, 
representative samples of wounded and non-wounded cuttings along with control ones at 2 weeks old from planting date their basal portions $(5 \mathrm{~cm})$ were collected, washed with tap water, rinsed twice with distilled water, dried, ground to fine powder and used for the chemical analysis. Nitrogen contents were determined according to the method described by Pregle, (1945) using micro-kjeldahl procedure. Carbohydrate contents were determined using the method of Walkely and Black, (1934) as described by Jackson, (1967). The results of both nitrogen and carbohydrate contents were presented as percentage of dry weight (\% D.W.). The $\mathrm{C} / \mathrm{N}$ ratio was calculated from the value of nitrogen and carbohydrate contents. Phenols content were determined according to the method outlined by Malick and Singh, (1980). The results were presented as $\mathrm{mg} / 100 \mathrm{~g}$ dry weight.

The experiment in the 2 tested seasons was designed in a complete randomized block design. The obtained data were subjected to analysis of variance and the means were compared using the "Duncan Multiple Range Test" (Duncan, 1955).

\section{RESULTS AND DISCUSSION}

According to the great similarity almost among the results values in the 2 tested seasons of either root ability parameters or chemical constituents in basal portion of the treated cuttings, the obtained results in the present study were presented and discussed as average values of both tested seasons.

The relationship between rooting ability parameters measured on the treated wounded and non-wounded cuttings and chemical constituents in basal portion of these cuttings was the major objective of the present research. The determined chemical constituents were nitrogen and carbohydrate contents, $\mathrm{C} / \mathrm{N}$ ratio and phenols content. The effect of tested treatments on such constituents was cleared from the results recorded in Table (1).

\section{Effect on nitrogen contents (\% D.W.)}

It can be noticed from the concerned data in Table (1) that $\mathrm{N}$ level in basal portion of non-wounded cuttings were significantly higher with the combined "T7" (IBA $\left.+\mathrm{V}_{\mathrm{B} 12}\right)$ treatment $(1.80 \%)$, followed by those of the combined " $\mathrm{T}_{6}$ " $\left(\mathrm{H}_{2} \mathrm{O}_{2}+\mathrm{V}_{\mathrm{B} 12}\right)$ treatment $(1.70 \%)$ as compared with those under the other treatments. The next major effect was to " $\mathrm{T}_{4}$ " $\left(\mathrm{V}_{\mathrm{B} 12}\right)$ treatment with an average $\mathrm{N}$ level of $1.68 \%$. The control cuttings $\left(\mathrm{T}_{1}\right)$, relatively, were the least in that respect $(1.61 \%)$. These results proved that effect of the combined treatments of $\mathrm{V}_{\mathrm{B} 12}$ was better than using either IBA " $\mathrm{T}_{2}$ " or $\mathrm{H}_{2} \mathrm{O}_{2}$ "T $\mathrm{T}_{3}$ solely on increasing $\mathrm{N}$ level, since the later 2 treatments, respectively, tabulated the average values 1.66 and $1.66 \%$ per cutting. Relatively, a higher $\mathrm{N}$ level of " $\mathrm{T}_{4}$ " $\left(\mathrm{V}_{\mathrm{B} 12}\right)$ treatment (1.68\%) supported our finding herein.

As for wounded cuttings, the results in the same table on line with those of non-wounded ones. The highest average of $\mathrm{N}$ levels was in cuttings of " $\mathrm{T}_{13}$ " $\left(\mathrm{H}_{2} \mathrm{O}_{2}+\mathrm{V}_{\mathrm{B} 12}\right)$ treatment $(1.85 \%)$ and " $\mathrm{T}_{11}$ " $\left(\mathrm{V}_{\mathrm{B} 12}\right)$ one (1.83\%). 
The relationship between endogenous $\mathbf{N}$ level and rooting ability

Average $\mathrm{N}$ level in basal portion of non-wounded cuttings at $1.62 \%$ "T5" and in wounded ones at $1.63 \%$ " $\mathrm{T}_{12}$ " illustrated a higher rooting percentage and induced adventitious roots of a higher number of adventitious primary roots. On the other hand, basal portion of cutting contained higher $\mathrm{N}$ level (" $T_{6} "$, " $\mathrm{T}_{7}$ ", " $\mathrm{T}_{11}$ ", and " $\mathrm{T}_{13}$ ") minimized these rooting ability parameters along with failed to induce secondary (lateral) roots (Figure 1). These results indicated that the presence of $\mathrm{N}$ contents in basal portion of both nonwounded and wounded guava cuttings in an appropriate level are necessary to increase rooting ability. Among the tested treatments, those determined $\mathrm{N}$ level of $1.62 \%$ " $\mathrm{T}_{5}$ " and "T $\mathrm{T}_{12}$ " were the most effective ones. It is important to state herein that $\mathrm{N}$ is essential in synthesis of nucleic acids and proteins. These products in turn are necessary for cell division to root initiation. In that respect Breen and Muraoka, (1973) suggested that seasonal variation of nutrients in plant occur according to movement of nutrients connected with sink and source relationship depending on growth rate. Therefore, $\mathrm{N}$ move into sink, such as new shoots and result in higher level in new shoots during growing period.

The above findings are assumed that high nitrogen contents in cuttings basal portion repress rooting ability. This agreed with Kim et al., (1977) and Hambrick et al., (1985) who reported that if $\mathrm{N}$ level in cuttings decrease below a certain level, root formation was decreased in spit of a high level of carbohydrates. In addition, they stated that the effect of $\mathrm{N}$ on rooting was related to carbohydrates content in cutting.

\section{Effect on carbohydrates content (\% D.W.)}

Endogenous carbohydrates in basal portion of non-wounded were significantly higher with $\mathrm{T}_{5}\left(\mathrm{H}_{2} \mathrm{O}_{2}+\mathrm{IBA}\right)$ treatment $(16.63 \%)$ than those of the other tratments. Cuttings of the treatments $\mathrm{T}_{3}\left(\mathrm{H}_{2} \mathrm{O}_{2}\right), \mathrm{T}_{4}\left(\mathrm{~V}_{\mathrm{B} 12}\right)$ and $\mathrm{T}_{6}\left(\mathrm{H}_{2} \mathrm{O}_{2}+\right.$ $\mathrm{V}_{\mathrm{B} 12}$ ) contained also high levels of carbohydrate contents. The average levels of the treatments were $16.55,16.55$ and $16.52 \%$, respectively. Minimum levels were in cuttings of $\mathrm{T}_{7}\left(\mathrm{IBA}+\mathrm{V}_{\mathrm{B} 12}\right)$ treatment $(16.35 \%)$ and $\mathrm{T}_{2}$ (IBA) treatment $(16.39 \%)$, whereas the least value $(15.91 \%)$ was in control one $\left(T_{1}\right)$. These findings pointed to $\mathrm{H}_{2} \mathrm{O}_{2}$ as the most effective tested chemical to increase endogenous carbohydrates in non-wounded cuttings followed by $\mathrm{V}_{\mathrm{B} 12 .}$

As for the treated wounded cuttings, the concerned results in the same table supported the superiority of $\mathrm{H}_{2} \mathrm{O}_{2}$, since among the tested treatments that of $\mathrm{H}_{2} \mathrm{O}_{2}$ and IBA $\left(\mathrm{T}_{12}\right)$ resulted in the treated cuttings significantly the highest level of carbohydrates (16.78\%). The next major levels were in cuttings of $\mathrm{T}_{10}\left(\mathrm{H}_{2} \mathrm{O}_{2}\right)$ and $\mathrm{T}_{14}\left(\mathrm{IBA}+\mathrm{V}_{\mathrm{B} 12}\right)$ treatments, both with an average of $16.60 \%$ per cutting, followed by those of $\mathrm{T}_{9}(\mathrm{IBA})$ and $\mathrm{T}_{13}\left(\mathrm{H}_{2} \mathrm{O}_{2}+\mathrm{V}_{\mathrm{B} 12}\right)$ treatments (16.41 and $16.39 \%$, respectively). Wounding treatment only (T8) significantly recorded the least level in that respect (16.27\%).

The relationship between endogenous carbohydrates and rooting ability

Results in the same table showed the contents of carbohydrate and those illustrated in Figures (1\&2) of rooting ability parameters measured greatly pointed to $T_{5}$ treatment to determine significantly the highest level of carbohydrates in non-wounded cuttings (16.63\%). Likewise, maximum 
carbohydrates level in wounded ones was under " $\mathrm{T}_{12}$ " treatment (16.78\%). The highest carbohydrate contents in these cuttings tabulated significantly the highest rooting percentage, number of adventitious primary and secondary (lateral) roots as well as adventitious primary root length per cutting specially in case of wounded cutting. The tabulated values for these root characteristics respectively, were $43.00 \%, 16.65$ adventitious primary roots, 4.70 secondary (lateral) roots and $5.77 \mathrm{~cm}$ in non-wounded cuttings with " $\mathrm{T}_{5}$ " treatment. The corresponding values in wounded cuttings with " $\mathrm{T}_{12}$ " treatment were $70.67 \%, 24.96$ adventitious primary roots, 8.58 secondary (lateral) roots and $8.38 \mathrm{~cm}$ per cutting.

On the other hand, in this experiment minimum level of total carbohydrates were in non-wounded cuttings of $\mathrm{T}_{1}$ and $\mathrm{T}_{7}$ treatments with the values of 15.91 and $16.35 \%$, respectively. Cuttings having such low level of carbohydrates either failing to form adventitious roots $\left(T_{1}\right)$ or produced roots of very poor characteristics with $6.05 \%$ rooting percentage, 3.67 adventitious primary roots and no secondary (lateral) roots per cutting. As for wounded cuttings almost a similar trend was observed, the lowest carbohydrate levels were in cuttings of $T_{11}$ and $T_{13}$ treatments. Cuttings of the former treatment recorded $5.59 \%$ rooting, 3.50 adventitious primary roots, $3.70 \mathrm{~cm}$ adventitious primary root length and no secondary (lateral) roots found. The corresponding values of the later treatment were $16.16 \%, 6.15$ adventitious primary roots, $3.71 \mathrm{~cm}$ adventitious primary root length and none secondary (lateral) roots.

The above mentioned results greatly proved that the high carbohydrate contents in basal portion coincided with the high rooting ability in the treated cuttings. This positive effect of carbohydrates is logically, basing on the statement that fructose and glucose are considered energy source for cell division in rooting. In addition storage carbohydrates is important for root formation not only as the main energy source but also as structural materials of cell to initiate root primordial (Nanda and Ananad, 1970; Greenwood and Berlyn, 1973). Our findings also agreed with Hartmann et al., (1990) who reported that the rooting capacity of many cuttings has been correlated with their carbohydrates content. YonKweon and KiSun, (1996) who worked on Abeliophyllum disyichum cuttings and Hussein, (2003) working on Beaumontia grandiflora cuttings indicated that cuttings of well rooting had relatively high content of total carbohydrates. More recent, Nag et al., (2004) with mung been cuttings in an attempt to identify some cellular contents at the base of hypocotyls cuttings that control adventitious root formation. They identified three phases of the adventitious root formation process, induction, initiation and expression. Each phase was characterized and controlled by endogenous certain chemical and biochemical compounds along with activities of some enzymes involving in rooting.

\section{Effect on $\mathrm{C} / \mathrm{N}$ ratio}

The effect of tested treatments on endogenous $\mathrm{C} / \mathrm{N}$ ratio in nonwounded cuttings under study came on line with that on endogenous carbohydrates in the same cuttings. Once again, non-wounded cuttings of " $\mathrm{T}_{5}$ " treatment $\left(\mathrm{H}_{2} \mathrm{O}_{2}+\mathrm{IBA}\right)$ calculated an average $\mathrm{C} / \mathrm{N}$ ratio (10.27) significantly higher than those of the other treatments. The next major ratio 
was in non-wounded cuttings of " $\mathrm{T}_{3}$ " treatment $\left(\mathrm{H}_{2} \mathrm{O}_{2}\right)$ with an average of 9.97 followed by " $\mathrm{T}_{2}$ " (IBA) and " $\mathrm{T}_{4}$ " $\left(\mathrm{V}_{\mathrm{B} 12}\right)$ treatments $(9.90$ and 9.88, respectively). Minimum $\mathrm{C} / \mathrm{N}$ ratio in that respect was in cuttings of " $\mathrm{T} 7$ " treatment (IBA $\left.+\mathrm{V}_{\mathrm{B} 12}\right)$ with 9.08 (Table 1).

As for wounded cuttings, the concerned results in the same table also in harmony with those tabulated for carbohydrate contents. Among the tested treatments, $\mathrm{T}_{12}\left(\mathrm{H}_{2} \mathrm{O}_{2}+\mathrm{IBA}\right)$ was the best to calculate significantly the higher ratio (10.32). It was also noticed that using these 2 chemical promoters together in one treatment $\left(T_{12}\right)$ much better than they applied solely $\left(T_{9}\right.$ and $\left.\mathrm{T}_{10}\right)$. On the other hand, minimum ratios were found in wounded cuttings of $\mathrm{T}_{13}\left(\mathrm{H}_{2} \mathrm{O}_{2}+\mathrm{V}_{\mathrm{B} 12}\right)$ and $\mathrm{T}_{11}\left(\mathrm{~V}_{\mathrm{B} 12}\right)$ treatments with the average ratios of 8.89 and 8.93 , respectively.

\section{The relationship between $\mathrm{C} / \mathrm{N}$ ratio and rooting ability}

According to the results in the table and those illustrated in Figures (1\&2), it was found that the relationship between $\mathrm{C} / \mathrm{N}$ ratio in cutting and its rooting ability was very similar to that between carbohydrates and rooting ability. Maximum $\mathrm{C} / \mathrm{N}$ ratio in non-wounded cuttings of " $\mathrm{T}_{5}$ " treatment and in wounded cuttings of " $\mathrm{T}_{12}$ " treatment makes these cuttings succeeded to form adventitious root of the highest qualities. They tabulated significantly higher rooting percentage ( 43.00 and $70.67 \%$ ), number of adventitious primary roots (16.65 and 24.96 roots), number of secondary (lateral) roots (4.70 and 8.58 roots) and adventitious primary root length $(5.77$ and $8.38 \mathrm{~cm})$, per cutting respectively. In this experiment, minimum $\mathrm{C} / \mathrm{N}$ ratios were in non-wounded cuttings of " $\mathrm{T}_{7}$ " treatment (9.08) and in wounded cuttings of " $\mathrm{T}_{11}$ " and " $\mathrm{T}_{13}$ " treatments (8.93 and 8.89). Cutting having these lowest ratios showed very poor rooting ability. Minimum rooting percentage (6.05, 5.59 and $16.16 \%$ ), number of adventitious primary roots (3.67, 3.50 and 6.15 roots), adventitious primary root length specialy with the later 2 treatments $(3.70$ and $3.71 \mathrm{~cm})$ and completely failed to induce secondary (lateral) roots.

The present part of study revealed that, the relationships among calculated $\mathrm{C} / \mathrm{N}$ ratios in basal portion of the treated non-wounded and wounded cuttings in relation to their rooting ability parameters measured obviously showed very similar behaviour to that of carbohydrate contents in the same cuttings. Therefore, it could be generally reported that high $\mathrm{C} / \mathrm{N}$ ratio in hardwood stem cuttings of guava is favorable to form good rooting. This finding was previously reported by YongKwean and KiSun, (1996) working on Abeliophyllum distichum cuttings; Mahros, (2000) on bougainvillea cuttings and Hussein9, (2003) on Thunbergia grandiflora cuttings. They indicated that the $\mathrm{C} / \mathrm{N}$ ratio may be an important factor influencing the root ability of cuttings, since the values of $\mathrm{C} / \mathrm{N}$ ratio were positively related to rooting percentage. 
J. Plant Production, Mansoura Univ., Vol. 1 (5), May, 2010

1

705 


\section{Effect on phenols content ( $\mathrm{mg} / \mathbf{1 0 0 \mathrm { g }}$ dry weight)}

Effect of the tested treatments on phenols content in basal portion of the treated cuttings was indicated from the concerned data in Table (1). From this table, it was cleared that among the tested cuttings those untreated control ones were determined significantly the highest phenols content $(0.222$ $\mathrm{mg} / 100 \mathrm{~g}$ D.W.). As for the effect on non-wounded cuttings, it can be arranged the treatments with respect to their effects on the amount of phenols content in descending order as $\mathrm{T}_{3}\left(\mathrm{H}_{2} \mathrm{O}_{2}\right), \mathrm{T}_{7}\left(\mathrm{IBA}+\mathrm{V}_{\mathrm{B} 12}\right), \mathrm{T}_{5}\left(\mathrm{H}_{2} \mathrm{O}_{2}+\right.$ IBA), $T_{2}$ (IBA), $T_{4}\left(V_{B 12}\right)$ and $\mathrm{T}_{6}\left(\mathrm{H}_{2} \mathrm{O}_{2}+\mathrm{V}_{\mathrm{B} 12}\right)$. The tabulated average phenols content for these treatments, respectively, were $0.118,0.104,0.081,0.066$, 0.054 and $0.044 \mathrm{mg} / 100 \mathrm{~g} \mathrm{D.W}$. These results indicated that phenols content in the basal portion of non-wounded cuttings were significantly affected by various growth and root promoters as well as the interactions among them.

The effect of the same treatments with wounding process as presented in the same table showed that cuttings of wounding treatment only $\left(T_{8}\right)$ contained significantly the greatest amount of phenols $(0.152 \mathrm{mg} / 100 \mathrm{~g})$, followed by those of " $\mathrm{T}_{10}$ " $\left(\mathrm{H}_{2} \mathrm{O}_{2}\right)$ treatment $(0.104 \mathrm{mg} / 100 \mathrm{~g})$. The wounded cuttings subjected to the treatments of "T9" (IBA) and " $\mathrm{T}_{13}$ " $\left(\mathrm{H}_{2} \mathrm{O}_{2}+\mathrm{V}_{\mathrm{B} 12}\right)$ came to the next order in that respect with the average values of 0.085 and $0.083 \mathrm{mg} / 100 \mathrm{~g}$, respectively. Otherwise, minimum amount was determined in cuttings of $\mathrm{T}_{12}\left(\mathrm{H}_{2} \mathrm{O}_{2}+\right.$ IBA) treatment $(0.059 \mathrm{mg} / 100 \mathrm{~g})$.

\section{The relationship between phenols content and rooting ability}

The results of phenols content in the cutting bases indicated that the root parameters of rooting ability measured were adversely affected by the total phenols in the treated cuttings, since the higher values were associated with the lower phenols content. This relationship was strongly cleared with cuttings of the control treatment " $\mathrm{T}_{1}$ " which were tabulated significantly the highest value of phenols content in cuttings base portion and they completely failed to induce adventitious roots. Otherwise, the lower phenols in cuttings of $T_{5}$ treatment were succeeded to form adventitious roots having rooting ability parameters of higher values.

As for wounded cuttings a similar relationship was detected. Maximum values of root characteristics measured were recorded for cuttings of " $\mathrm{T}_{12}$ " treatment which were determined the lowest amount of phenols content in the basal portion of these cuttings. These findings are in agreement with the results of Hussein, (2003) who mentioned that the highest rooting percentage of Beaumontia grandiflora cuttings was associated with the lowest level of total phenols in the basal parts of cuttings.

The above negative relationship between phenols content in the treated cuttings and their root ability can be explained as the appropriate amount and kind of phenols in non-wounded and wounded cuttings of the best treatments are efficient to act with auxins. The workers in this subject concluded that the regulatory effect of phenols is not primarily through their effect on IAA-oxidation. Kefeli and Kadyrov, (1971) suggested that the effect of phenols are primarily on metabolic systems rather than on hormonal systems. Additional explanation was indicated from the study of Nitsch and Nitsch, (1962) who reported that monophenolics and o-diphenolics are likewise, respectively stimulants and inhibitors of IAA-oxidase. 
J. Plant Production, Mansoura Univ., Vol. 1 (5), May, 2010

Figure (1): Diagram showing the effect of various growth and root promoter treatments on rooting ability parameters of nonwounded and wounded hardwood stem cuttings of guava trees at 3-month-old from planting date: rooting \% (A), Adventitious primary roots number (B), Adventitious primary root length (C) and secondary (lateral) roots number (D) per cutting as an average value of the 2 tested seasons. 
Samaan, L. G. et al.

Figure (2): Photograph showing the effect of $T_{12}, T_{5}, T_{1}, T_{7}$ and $T_{13}$ treatments on adventitious primary roots number per hardwood stem cutting of guava trees at 3 months from planting date.

$\mathbf{T}_{1}$ = Dipping cutting in water for $\mathbf{3 0}$ second (control).

$\mathrm{T}_{5}=$ Dipping non-wounded cutting in $\mathrm{H}_{2} \mathrm{O}_{2}$ at $3.5 \%$ and in IBA at $4000 p p m$ for 30 second each.

$\mathrm{T}_{12}=$ Dipping wounded cutting in $\mathrm{H}_{2} \mathrm{O}_{2}$ at $3.5 \%$ and in IBA at $4000 \mathrm{ppm}$ for 30 second each.

The polyhydroxy phenolics are in many instances stimulators of growth at low concentration and become inhibitory at higher concentrations. In the same line, Pridham, (1965) indicated that the inhibitory effects of phenols on growth and rooting are commonly attributed to the enhancement of indoleacetic oxidase, but it is very probable that other actions such as interference with oxidative phosphorylation are involved.

Regarding the chemical composition of the basal portion in hardwood stem cuttings sourced from guava trees, it is worthy to note that the increase in rooting percentage and root characteristics was affected by the presence of nitrogen contents in appropriate level, low phenol contents and strongly associated with the increase in the total carbohydrates content and the $\mathrm{C} / \mathrm{N}$ ratio. Generally, it can be also concluded that increasing percentage and other root parameters are directly and indirectly affected by the chemical constituents of cuttings basal portion. In that respect, no reason to believe that auxins are ordinarily a rate limiting factor in root induction and growth (Leopold and Kriedemann, 1975). 


\section{REFERENCES}

Bleasdale, J.K.A. (1984). Plant Physiology in Relation to Horticulture. $2^{\text {nd }}$ Ed. The Mac Millan press Ltd. London, pp: 92-95.

Breen, P.J. and Muraoka, T. (1973). Effect of indolebutyric acid on distribution of 14C-photosynthate in softwood cuttings of 'Marianna 2624' plum. J. Amer. Soc. Hort. Sci. 98: 436-439.

Duncan, B.D. (1955). Multiple range and multiple tests. Biometrics, 11: 1-42.

Greenwood, M.S. and Berlyn, G.P. (1973). Sucrose-indole-3-acetic acid interactions on root generation by pinus lambertiana embryo cuttings. Amer. J. Bot. 60: 42-47.

Hambrick, C.E.; Davies, F.T.; Jr., and Pemberton, H.B. (1985). Effect of cutting position and carbohydrate/nitrogen ratio on seasonal rooting of Rosa multiflora. HortScience, 20: 570.

Hartmann, H.T. and Kester, D.E. (1985). Plant propagation, principles and practices $3^{\text {rd }}$. Ed. Englewood Cliffs, N.J. Prentic Hall Inc. New York, PP. 481

Hartmann, H.T.; Kester, D.E. and Davies, F.T.Jr. (1990). Plant propagation: principles and practices. 5th Ed. Prentice Hall, Inc., Englewood Cliffs, New Jersey.

Hussein, M.M.M. (2003). Effect of planting dates and indole-butyric acid on rooting of Beaumontia grandiflora, Wallich. Cuttings and consequent plant growth. Arab Univ. J. Agric. Sci., Ain Shams Univ., Cairo, 11: 765-787.

Jackson M. L. (1967). "Soil chemical analysis advanced course" puble. By the author, Dept. of Soil, Univ. of Wise., Madison 6, Wishensin, U. S. A.

Kefeli, V.I. and Kadyrov, C.S. (1971). Natural growth inhibitors, their chemical and physiological properties. Ann. Rev. Plant physiol., 22: 185-196.

Kim, Y.J.; Pyo, H.K.; Yu, T.Y. and Yeam, D.Y. (1977). Physiological mechanism of seasonal fluctuation of rooting in Korean boxwood (Buxus microphylla var. koreana Nakai) cutting. J. Kor. Soc. Hort. Sci., 18: 63-87.

Leopold, A.C. and Kriedemann, P.E. (1975). Plant growth and development. Tata McGrane-Hill puplishing co. LTD. 2nd Edition, New York, pp 545.

Luis, A.S.; Raul, S. and Rodrigo, T.J.C. (1986). Vegetative propagation of guava by different types of cuttings. Hort.Sci., 21: 663.

Mahros, O.M., (2000). Rooting and growth of some types of bougainvillea cuttings under IBA stimulation. Assuit J. Agric. Sci., 31: 19-37.

Malick, C. P. and Singh, M. B. (1980). Plant Enymology and Histo Enzymology Kalyani Publishers New Delhi P 286.

Mukhopadhaya, T.P. and sen, S.K. (1998). Propagation of horticultural crops, Guava. Naya Prokash, 206 Bidhan Sareni, Calcutta, 700006: 289-295 (India).

Mukhtar, A.; Iftikhar, A.; laghari, M.H. and Hidayatullah (1998). Effect of growth regulators on rooting in softwood cuttings of guava under mist condition. Sarhad J. Agric. Res., 14: 423-425. 
Nag, S.; Saha, K. and Choudhuri, M.A. (2004). Role of auxin and polyamines in adventitious root formation in relation to changes in compounds involved in rooting. Journal of plant growth regulation, 20(2): 182-194.

Nanda, K.K. and Ananad, V.K. (1970). Seasonal changes in auxin effect on rooting of stem cuttings of populous nigra and its relationship with mobilization of starch. Physiol. Plant., 23: 99-107.

Nitsch, J.P. and Nitsch, C. (1962). Composés phenoliques et croissance vegetale. Ann. Physiol. Veg., 4: 211-225.

Pregle, E. (1945). "Quantitative Organic Micro-analysis". 4th ED. J. Chudrial, London.

Pridham, J.B. (1965). Low molecular weight phenols in higher plants. Ann. Rev. Plant physiol., 16: 13-36.

Shin, H.K.; Chun, C.K. and Choi, S.T. (1988). Seasonal changes of rooting ability in herbaceous cutting of Gypsophila paniculata L. CV. Bristol Fairy. J. Kor. Soc. Hort. Sci., 29: 319-327.

Tahir, F.M.; Pervez, M.A. and Ahmad, R. (1998). Effect of growth Regulators on rooting performance of stem cutting in guava (Psidium guajava L.). Pakistan Journal of Biological Sciences. Pakistan, 1(2): 132-133.

Um, S.H. and Yeam, D.Y. (1987). Studies on the propagation of forsythia species by cutting. J. Amer. Soc. Hort. Sci. 28:77-87.

Walkely, A. and Black, I.A. (1934). An examination of Degtjareff method for determining soil organic matter and a proposed modification of the chromic acid titration method. Soil Sci., 37: 29-38.

YongKweon, Y. and KiSun, K. (1996). Seasonal variation in rooting ability, plant hormones, carbohydrate, nitrogen, starch and soluble sugar contents in cuttings of white forsythia (Abeliophyllum distichum Nakai). J. Kor. Soc. Hort. Sci., 37(4): 554-560.

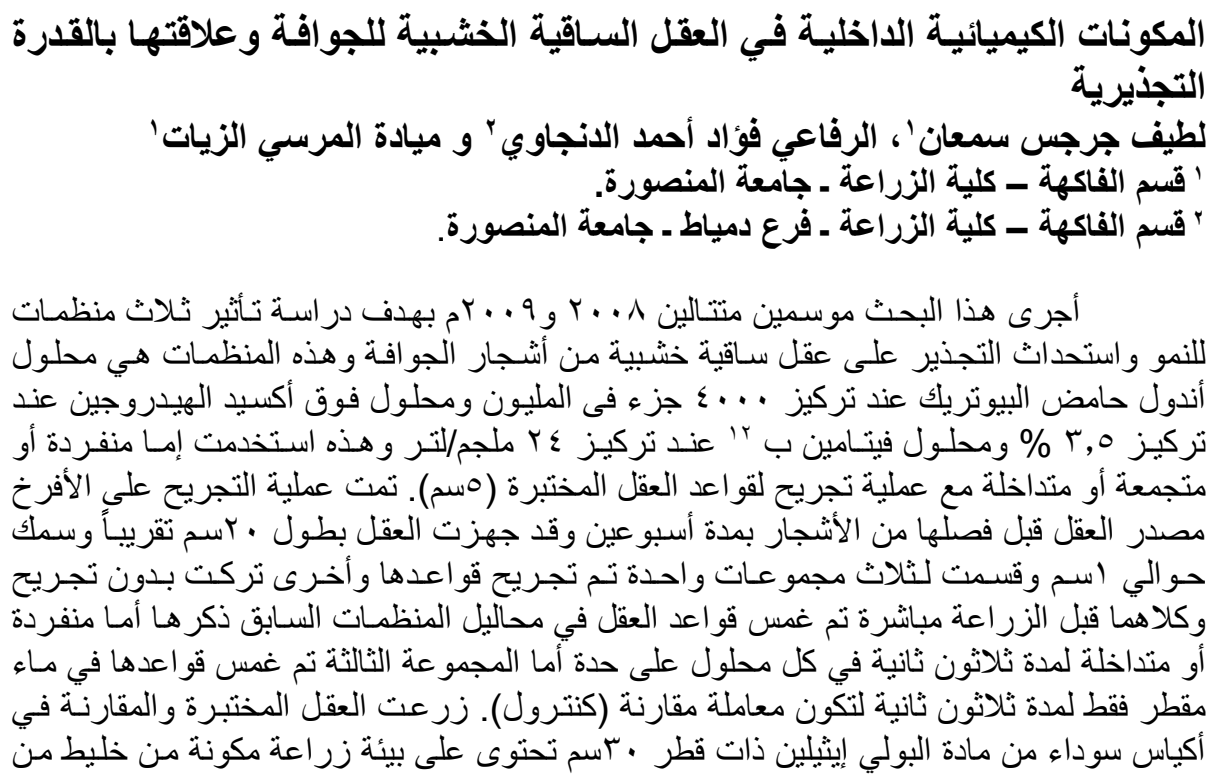




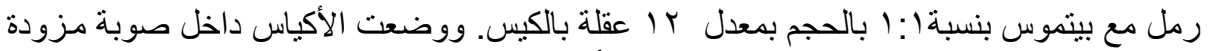

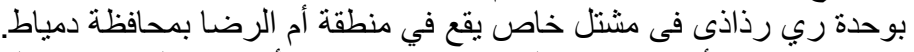

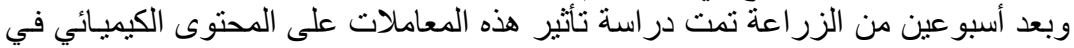

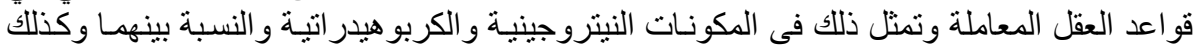

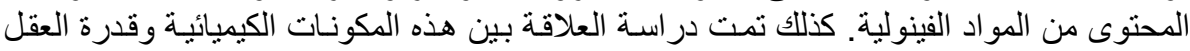

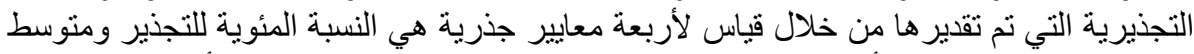

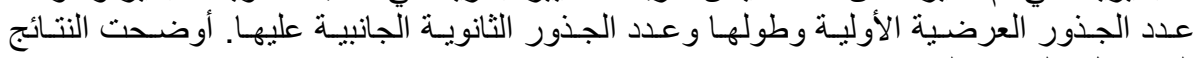

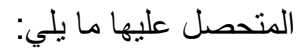

ا - يتأثر محتوى المكونات الكيميائية تحت الدراسة في قو اعد العقل المعاملة في كلا المجمو عتين

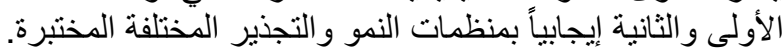

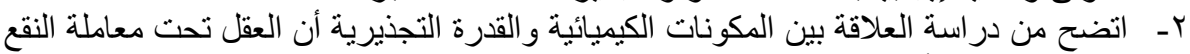

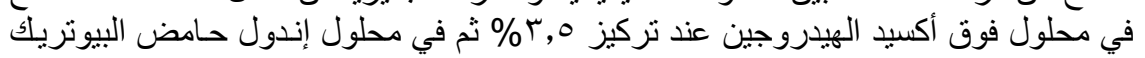

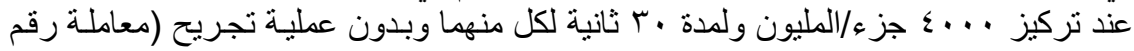

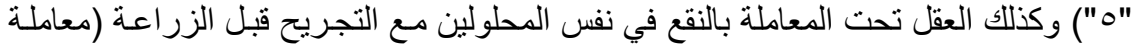

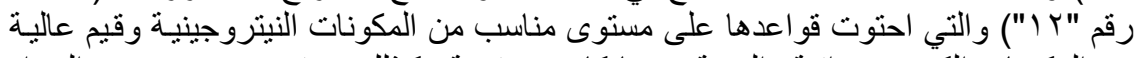

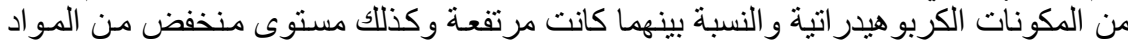

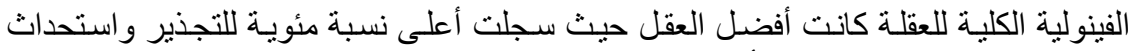
جذور عرضية ذات الصفات الأفضل وذللك مقارنة بنفس القياسات على العقل العقل تحت المعاملات الأخرى و المعاملة القياسية.

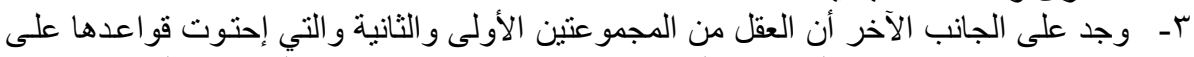

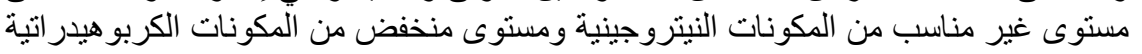

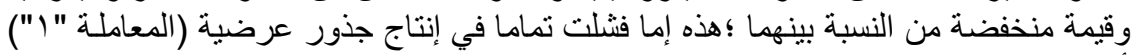

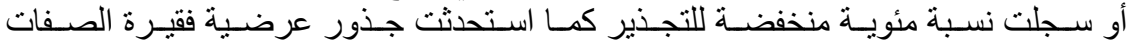

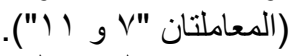

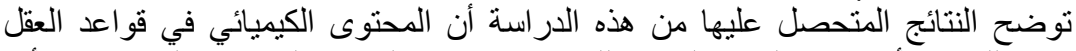

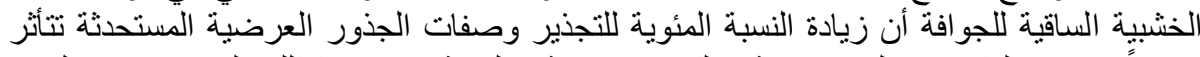

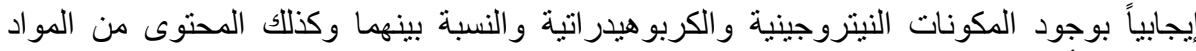

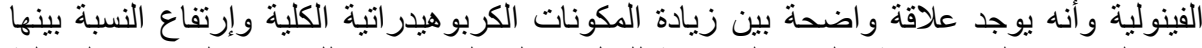

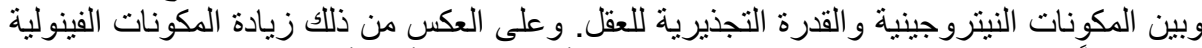

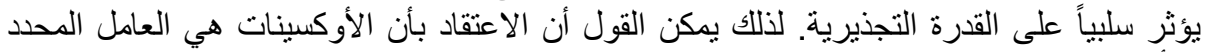

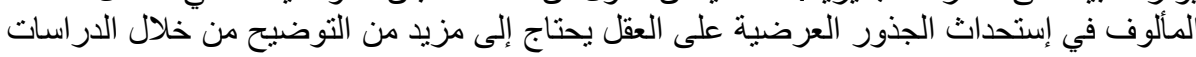

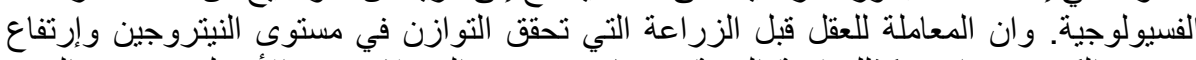

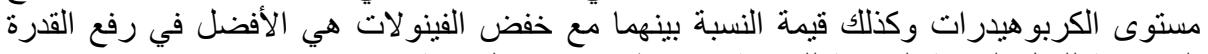
التجذيرية للعقل الساقية الخشبية للجو افة تحت ظروف لنئ هذه التجربة.

كلية الزراعة - جامعة المنصورة كلية الزراعة - جامعة أسيوط
قام بتحكيم البحث أ. أد / محسن فهمى محمد البحد أ.د / احمد مخلص السيسى فحمى محمى 
Samaan, L. G. et al. 
Table (1): Effect of various growth and root promoting regulators along with wounding process on nitrogen, carbohydrate, $\mathrm{C} / \mathrm{N}$ ratio and phenol contents in basal portion $(5 \mathrm{~cm})$ of guava cuttings after 2 weeks from planting date during2008 and 2009 Seasons.

\begin{tabular}{|c|c|c|c|c|c|c|c|c|c|c|c|c|c|}
\hline \multirow[b]{2}{*}{ Cutting Treatment } & \multirow[b]{2}{*}{$\begin{array}{c}\text { Sym- } \\
\text {-bol }\end{array}$} & \multicolumn{3}{|c|}{ Nitrogen (\%D.W.) } & \multicolumn{3}{|c|}{ Carbohydrate (\%D.W.) } & \multicolumn{3}{|c|}{$\mathrm{C} / \mathrm{N}$ ratio } & \multicolumn{3}{|c|}{ Phenols (mg/100g) } \\
\hline & & 2008 & 2009 & Aver. & 2008 & 2009 & Aver. & 2008 & 2009 & Aver. & 2008 & 2009 & Aver. \\
\hline \multicolumn{14}{|c|}{ Non-wounded } \\
\hline $\begin{array}{l}\text { Dipping in water } \\
\text { (control) }\end{array}$ & $\mathrm{T}_{1}$ & $1.61 \mathrm{e}^{*}$ & $1.61 \mathrm{e}$ & 1.61 & $15.90 \mathrm{~h}$ & $15.91 \mathrm{~h}$ & 15.91 & $9.88 \mathrm{f}$ & $9.88 \mathrm{f}$ & 9.88 & $0.222 \mathrm{a}$ & $0.222 \mathrm{a}$ & 0.222 \\
\hline Dipping in IBA & $\mathrm{T}_{2}$ & $1.67 \mathrm{~d}$ & $1.64 \mathrm{de}$ & 1.66 & $16.39 \mathrm{e}$ & $16.38 \mathrm{ef}$ & 16.39 & $9.81 \mathrm{~g}$ & $9.99 \mathrm{~d}$ & 9.90 & $0.065 \mathrm{f}$ & $0.066 \mathrm{f}$ & 0.066 \\
\hline Dipping in $\mathrm{H}_{2} \mathrm{O}_{2}$ & $\mathrm{~T}_{3}$ & $1.66 \mathrm{~d}$ & $1.66 \mathrm{~cd}$ & 1.66 & $16.55 \mathrm{~cd}$ & $16.54 \mathrm{c}$ & 16.55 & $9.97 \mathrm{~d}$ & $9.96 \mathrm{e}$ & 9.97 & $0.118 \mathrm{c}$ & $0.118 \mathrm{c}$ & 0.118 \\
\hline Dipping in $V_{\mathrm{B} 12}$ & $\mathrm{~T}_{4}$ & $1.68 \mathrm{~cd}$ & $1.67 \mathrm{~cd}$ & 1.68 & $16.55 \mathrm{~cd}$ & $16.54 \mathrm{c}$ & 16.55 & $9.85 \mathrm{f}$ & $9.90 \mathrm{f}$ & 9.88 & $0.054 \mathrm{~g}$ & $0.053 \mathrm{~g}$ & 0.054 \\
\hline Dipping in $\left(\mathrm{H}_{2} \mathrm{O}_{2}+\mathrm{IBA}\right)$ & $T_{5}$ & $1.62 \mathrm{e}$ & $1.62 \mathrm{de}$ & 1.62 & $16.63 \mathrm{~b}$ & $16.62 \mathrm{~b}$ & 16.63 & $10.27 \mathrm{~b}$ & $10.26 \mathrm{~b}$ & 10.27 & $0.081 \mathrm{e}$ & $0.081 \mathrm{e}$ & 0.081 \\
\hline Dipping in $\left(\mathrm{H}_{2} \mathrm{O}_{2}+\mathrm{V}_{\mathrm{B} 12}\right)$ & $\mathrm{T}_{6}$ & $1.70 \mathrm{c}$ & $1.69 \mathrm{c}$ & 1.70 & $16.52 \mathrm{~d}$ & $16.52 \mathrm{c}$ & 16.52 & $9.72 \mathrm{~h}$ & $9.78 \mathrm{~g}$ & 9.75 & $0.044 \mathrm{~h}$ & $0.043 \mathrm{~h}$ & 0.044 \\
\hline Dipping in $\left(\mathrm{IBA}+\mathrm{V}_{\mathrm{B} 12}\right)$ & $\mathrm{T}_{7}$ & $1.80 \mathrm{~b}$ & $1.80 \mathrm{~b}$ & 1.80 & $16.34 \mathrm{f}$ & $16.35 \mathrm{f}$ & 16.35 & $9.08 \mathrm{i}$ & $9.08 \mathrm{~h}$ & 9.08 & $0.103 \mathrm{~d}$ & $0.104 \mathrm{~d}$ & 0.104 \\
\hline \multicolumn{14}{|c|}{ Wounded } \\
\hline Wounding only & $\mathrm{T}_{8}$ & $1.62 \mathrm{e}$ & $1.64 \mathrm{de}$ & 1.63 & $16.26 \mathrm{~g}$ & $16.28 \mathrm{~g}$ & 16.27 & $10.04 \mathrm{c}$ & $9.93 \mathrm{e}$ & 9.99 & $0.151 \mathrm{~b}$ & $0.153 \mathrm{~b}$ & 0.152 \\
\hline Wounding + IBA & $\overline{T_{9}}$ & $1.65 \mathrm{~d}$ & $1.65 \mathrm{ce}$ & 1.65 & $16.41 \mathrm{e}$ & $16.41 \mathrm{~d}$ & 16.41 & $9.95 \mathrm{de}$ & $9.95 \mathrm{e}$ & 9.95 & $0.084 \mathrm{e}$ & $0.085 \mathrm{e}$ & 0.085 \\
\hline Wounding $+\mathrm{H}_{2} \mathrm{O}_{2}$ & $T_{10}$ & $1.67 \mathrm{~d}$ & $1.65 \mathrm{ce}$ & 1.66 & $16.59 \mathrm{c}$ & $16.60 \mathrm{~b}$ & 16.60 & $9.93 \mathrm{e}$ & $10.06 \mathrm{c}$ & 10.00 & $0.104 \mathrm{~d}$ & $0.103 \mathrm{~d}$ & 0.104 \\
\hline Wounding $+\mathrm{V}_{\mathrm{B} 12}$ & $T_{11}$ & $1.82 \mathrm{ab}$ & $1.83 \mathrm{ab}$ & 1.83 & $16.28 \mathrm{~g}$ & $16.30 \mathrm{~g}$ & 16.29 & $8.95 \mathrm{j}$ & $8.91 \mathrm{i}$ & 8.93 & $0.067 f$ & $0.069 \mathrm{f}$ & 0.068 \\
\hline Wounding $+\left(\mathrm{H}_{2} \mathrm{O}_{2}+\mathrm{IBA}\right)$ & $T_{12}$ & $1.62 \mathrm{e}$ & $1.63 \mathrm{de}$ & 1.63 & $16.77 \mathrm{a}$ & $16.78 \mathrm{a}$ & 16.78 & $10.35 \mathrm{a}$ & $10.29 \mathrm{a}$ & 10.32 & $0.058 \mathrm{fg}$ & $0.059 \mathrm{~g}$ & 0.059 \\
\hline Wounding $+\left(\mathrm{H}_{2} \mathrm{O}_{2}+\mathrm{V}_{\mathrm{B} 12}\right)$ & $T_{13}$ & $1.84 \mathrm{a}$ & $1.85 \mathrm{a}$ & 1.85 & $16.39 \mathrm{e}$ & 16.39de & 16.39 & $8.91 \mathrm{k}$ & $8.86 \mathrm{j}$ & 8.89 & $0.082 \mathrm{e}$ & $0.083 \mathrm{e}$ & 0.083 \\
\hline Wounding+(IBA+V $\left.\mathrm{V}_{\mathrm{B} 12}\right)$ & $T_{14}$ & $1.62 \mathrm{e}$ & $1.62 \mathrm{de}$ & 1.62 & $16.59 \mathrm{c}$ & $16.61 \mathrm{~b}$ & 16.60 & $10.24 \mathrm{~b}$ & $10.25 \mathrm{~b}$ & 10.25 & $0.065 f$ & $0.066 \mathrm{f}$ & 0.066 \\
\hline
\end{tabular}

Value". 